\title{
Evaluating the Impact of Manufacturing Extension Services on Establishment Performance
}

DOI:

$10.1177 / 0891242417744050$

\section{Document Version}

Accepted author manuscript

Link to publication record in Manchester Research Explorer

\section{Citation for published version (APA):}

Lipscomb, C. A., Youtie, J., Shapira, P., Arora, S., \& Krause, A. (2017). Evaluating the Impact of Manufacturing Extension Services on Establishment Performance. Economic Development Quarterly.

https://doi.org/10.1177/0891242417744050

\section{Published in:}

Economic Development Quarterly

\section{Citing this paper}

Please note that where the full-text provided on Manchester Research Explorer is the Author Accepted Manuscript or Proof version this may differ from the final Published version. If citing, it is advised that you check and use the publisher's definitive version.

\section{General rights}

Copyright and moral rights for the publications made accessible in the Research Explorer are retained by the authors and/or other copyright owners and it is a condition of accessing publications that users recognise and abide by the legal requirements associated with these rights.

\section{Takedown policy}

If you believe that this document breaches copyright please refer to the University of Manchester's Takedown Procedures [http://man.ac.uk/04Y6Bo] or contact uml.scholarlycommunications@manchester.ac.uk providing relevant details, so we can investigate your claim.

\section{OPEN ACCESS}


Author Accepted Manuscript. Published version available as: CA Lipscomb, J Youtie, P Shapira, S Arora, A Krause (2017). "Evaluating the Impact of Manufacturing Extension Services on Establishment

Performance," Economic Development Quarterly. https://doi.org/10.1177/0891242417744050

\title{
Evaluating the Impact of Manufacturing Extension Services on
}

\section{Establishment Performance}

\author{
Clifford A. Lipscomb $b^{\mathrm{a}, *}$ \\ Jan Youtie \\ Philip Shapira ${ }^{c}$ \\ Sanjay Arora ${ }^{\mathrm{d}}$ \\ Andy Krause
}

April 2017

a. Greenfield Advisors, 106 N. Bartow Street, Cartersville, GA 30120; Phone: +1 (770) 334-3952;

cliff@greenfieldadvisors.com

b. Enterprise Innovation Institute, Georgia Institute of Technology, Atlanta, GA 30308;

c. Manchester Institute of Innovation Research, Alliance Manchester Business School, University of Manchester, Manchester M13 9PL, UK, and School of Public Policy, Georgia Institute of Technology, Atlanta, GA 30332-0345

d. American Institutes for Research, Washington, DC 20007

e. Department of Property, University of Melbourne, Australia

* Corresponding Author 


\begin{abstract}
This study examines the effects of receipt of business assistance services from the Manufacturing Extension Partnership (MEP) on manufacturing establishment performance. Our results generally indicate that MEP services had positive and significant impacts on establishment productivity and sales per worker for the 2002-2007 period with some exceptions based on employment size, industry, and type of service provided. MEP services also increased the probability of establishment survival for the 1997-2007 period. Regardless of econometric model specification, MEP clients with 1-19 employees have statistically significant and higher levels of labor productivity growth. We also observed significant productivity differences associated with MEP services by broad sector, with higher impacts over the 2002-2007 time period in the durable goods manufacturing sector. The study further finds that establishments receiving MEP assistance are more likely to survive than those that do not receive MEP assistance.
\end{abstract}




\section{INTRODUCTION}

This study examines the effects of receipt of business assistance services from the Manufacturing Extension Partnership (MEP) on manufacturing establishment performance. The study seeks to advance previous work on the effect of manufacturing extension services on establishment productivity. Examining the determinants of manufacturing establishment performance is important because U.S. industry continues to face challenges due to the increasingly competitive global business environment. Previous work on manufacturing establishment productivity has examined an array of factors, including plant ownership change, technology adoption, and deregulation. This paper adds consideration of business assistance services as a potential productivity determinant, specifically services of the Manufacturing Extension Partnership (MEP) program, which is administered by the National Institute of Standards and Technology (NIST). These business assistance services are delivered at the establishment level; to gauge the effects of such services, the measurement of productivity effects must take place at the establishment level as well. However, publicly available establishment-level productivity information is not accessible. Therefore, this work assesses the performance of MEP-assisted manufacturing establishments by linking establishment-level MEP data on business assistance recipients to establishment-level data from the U.S. Census Bureau.

The methodology used in this paper draws on two prior studies that examined the effect of the MEP program on manufacturing establishment performance. The first study, by Jarmin (1999), was conducted on manufacturing performance data for the 1987 to 1992 period. This time period was prior to the full roll-out of the MEP program in 1999. The second study was performed by a team from SRI International and the Georgia Institute of Technology on manufacturing performance data covering the 1997 to 2002 period (Ordowich et al., 2012). Both of these studies assessed the impact of MEP services on manufacturing productivity, sales, and employment growth. 
This paper extends this body of economic development evaluation studies by using a novel fuzzy logic matching program to confirm that MEP data and Census data are linked to the correct establishment and by updating the analysis with data from the 2002 to 2007 period. In addition, we also analyze establishment survival by testing the ability of establishments to maintain operations from an earlier to a later period. Generally, we find that MEP services had a statistically significant and positive impact on establishment productivity and sales per worker for the 2002-2007 period, with some exceptions. Specifically, we find that 1) smaller establishments receiving MEP services experience statistically significant and positive labor productivity growth across several econometric specifications, 2) durable goods manufacturing establishments receiving MEP services experience statistically significant productivity increases, and 3) receipt of MEP services increases manufacturing establishments' likelihood of survival.

In the section below, we begin with an overview of the MEP program. In Section 3, we summarize the results of the Jarmin (1999) and Ordowich et al. (2012) studies. Section 4 describes the methodology used in this paper, which involves linking information from MEP project information files (PIF) and customer information files (CIF) to databases from the U.S. Census Bureau. Section 5 describes the results of our study. Finally, we conclude with some implications of the results.

\section{THE MANUFACTURING EXTENSION PARTNERSHIP}

The MEP program provides business, technology, and other forms of assistance, typically to existing (as opposed to startup), small and midsize manufacturing establishments (Shapira et al., 2015). The program deploys a network of manufacturing experts (also known as manufacturing extension agents) with centers in all 50 U.S. states and Puerto Rico. The aim of the MEP program is to strengthen U.S. manufacturing competitiveness. The program was established through the 
Omnibus Trade and Competitiveness Act of 1988, which created the first three centers, with additional centers added such that a national system was in place by the mid-1990s. ${ }^{1}$

The total MEP annual system budget is about $\$ 300$ million (National Research Council, 2013, p. 19). The federal government awards about one-third of funds for the program, which the centers match from state funds, client fees, and other sources. Over half $(55 \%)^{2}$ of the centers operate as not-for-profit organizations (under section 501(c)(3) of the Internal Revenue Service code), with the others operating as university-based or state government-run programs.

The essential rationale for the MEP and similar technology and innovation advisory services in other countries is that existing small and mid-size establishments often face market imperfections and other systematic challenges in acquiring and deploying information, expertise, skills, and other resources. These issues lead to difficulties in technological and business upgrading, contributing in turn to lagging productivity, innovativeness, and competitiveness among many of these establishments (NAPA, 2003; National Research Council, 2013). The MEP's underlying program theory seeks to bridge these gaps through services that directly provide expertise, diagnostics, mentoring, training, and other support to help manufacturing establishments to upgrade, as well as access and referrals to other public and private resources (Shapira and Youtie, 2014). The small and medium-sized firms that engage with the MEP do so because its services are customized to their needs; equivalent private sector sources are either more expensive or not available, the MEP's services are oriented to business outcomes (rather than to research), and it offers independent yet comprehensive access to a range of expertise. If they are effective, MEP services should prompt intermediate business actions (including, but not limited to, equipment investment, enhanced plant layouts, employee training, process and quality improvements, cost reductions, and new products

\footnotetext{
${ }^{1}$ For a review of the development and operations of the MEP, see National Research Council (2013).

${ }^{2}$ This percentage is based on 58 centers (excluding non-operational centers in Alaska and Florida).
} 
and marketing strategies) leading to improved business performance outcomes such as enhanced productivity, sustainability, and growth for its clients.

The MEP flexibly operates through a decentralized network in which each center addresses its local conditions and the needs of manufacturers in that region to enhance their productivity. MEP centers deliver services with some mix of in-house specialists and third-party providers. More than 1,400 non-federal staff and over 2,400 third-party service providers are involved in service delivery (National Research Council, 2013, p. 15). MEP services are delivered through assessments of all aspects of a company's business or specific functional areas following a variety of outreach activities, one-on-one technical engagements to address a particular problem, hosting manufacturing networks for knowledge and current practice sharing, and training events depending on the needs and preferences of the manufacturer. Currently, the MEP serves about 7,000 to 8,000 clients annually through about 12,000 projects. ${ }^{3}$ NIST MEP oversees the governance structure of the system and maintains an extensive program of monitoring and evaluation.

\section{PRIOR STUDIES OF THE MEP AND MANUFACTURING PERFORMANCE}

A series of studies, using a broad range of methods, have examined various aspects of the performance and impact of the MEP in the U.S. and other technology extension and advisory services outside of the U.S. (For reviews of these studies, see Youtie, 2013; and Shapira and Youtie, 2014.) In this paper, we particularly focus on two earlier benchmark national studies of the effects of the MEP on client performance using non-assisted control groups. These benchmark studies are overviewed in the following two sections.

\footnotetext{
${ }^{3}$ National Research Council (2013, p. 57). According to this study, MEP services peaked most recently in FY 2007, with 9,000 clients served through some 14,500 projects.
} 


\subsection{Study 1: Jarmin}

Jarmin (1999) estimated the effect of MEP services on the productivity of establishments. His analysis was based on an augmented Cobb-Douglas production function with physical capital, employment, and other plant characteristics as shown in the equation below. ${ }^{4}$

$$
Y_{i t}=A e^{\delta E x t_{i t}} K_{i t}^{\beta} L_{i t}^{\eta} e^{\varepsilon_{i t}}
$$

This equation serves as the theoretical basis for all of the analyses that follow, where $\mathrm{Y}_{\text {it }}$ is valueadded for establishment $\mathrm{i}$ in period $\mathrm{t}, \mathrm{L}_{\mathrm{it}}$ is employment for establishment $\mathrm{i}$ in period $\mathrm{t}$, $\mathrm{K}_{\mathrm{it}}$ is book value of the capital stock of plant $\mathrm{i}$ in period $\mathrm{t}, \boldsymbol{\varepsilon}_{i t}$ is the error term, and $\mathrm{Ext}_{\mathrm{it}}$ is a dummy variable equal to 1 if establishment i received MEP services in period t, 0 otherwise.

Jarmin began his analysis by performing simple ordinary least squares (OLS) analysis. He then used a Heckman (1976) two-stage model to control for selection bias. The selection model used a dummy variable for whether or not the plant was located in a Metropolitan Statistical Area (MSA) that contained a manufacturing extension center as an instrument for the likelihood of being an MEP client. This variable was found to be associated with client standing (Jarmin, 1999, p. 111).

Jarmin specified the Cobb-Douglas production function as a linear regression equation by taking the natural logarithm of the Cobb-Douglas equation and rearranging the results. He obtained the following regression equation:

$$
\Delta \log \left(\frac{Y}{L}\right)_{i}=\alpha+\delta E x t_{i}+\beta \Delta \log \left(\frac{K}{L}\right)_{i}+(\mu-1) \Delta \log (L)_{i}+\varepsilon_{i}
$$

In Equation 2, the deltas $(\Delta s)$ reflect changes in the value of a variable between 1987 and 1992, and the parameter $\mu$ measures deviations from constant returns to scale. The dependent variable in

\footnotetext{
4 This model is based on the work of Solow (1957) and the augmentation of this function by Griliches (1996) with the stock of research expenditures accumulated by the establishment.
} 
Equation 2 is the percentage change in labor productivity between 1987 and 1992. (Note that in our analyses we have measured changes for the periods 1997-2007 and 1997-2002, as well as for 20022007.) The impact of the MEP program is measured by the parameter $\delta$, which measures the percentage difference in productivity between client and non-client plants. This formulation assumes that receiving MEP services would increase the productivity of a small plant by the same percentage as it would a large plant. Using Equation 2, Jarmin estimated two OLS models, one for all plants $(\mathrm{N}$ $=15,263)$ and one with plants with 19 to 500 employees $(\mathrm{N}=7,782)$.

In addition to estimating the OLS equation above, Jarmin (1999) estimated two more models (using the same plant size delineations) with two-digit standard industrial classification (SIC) dummies to control for industry differences as shown in the equation below.

$$
\Delta \log \left(\frac{Y}{L}\right)_{i}=\alpha+\delta E x t_{i}+\beta \Delta \log \left(\frac{K}{L}\right)_{i}+(\mu-1) \Delta \log (L)_{i}+\lambda_{1 \ldots N} S I C_{i}+\varepsilon_{i}
$$

\subsection{Study 2: Ordowich et al.}

Jarmin faced several limitations. He was only able to measure whether or not an establishment received MEP services between 1987 and 1992. Data on the level and type of treatment were not of sufficient quality for his analyses. Likewise, his study was situated in a period before nationwide establishment of the MEP, when there were only a few centers funded. To extend the Jarmin modeling effort, Ordowich et al. (2012) studied the effect of MEP services on labor productivity and other outcome variables. Their study used new data to run a number of additional OLS models replacing the binary treatment variable in the equations above $\left(\mathrm{Ext}_{\mathrm{i}}\right)$ with a variety of other measures. The treatment measures used included level of treatment (e.g. number of engagements, cumulative hours of MEP assistance, cumulative dollar amount paid by establishments 
for assistance), period of treatment, and type of treatment (e.g. delivery mode, type of assistance received, and substance of assistance received).

Ordowich et al. (2012) used three databases: one with MEP client engagements occurring between 1997 and 2002, another with demographic information for each client, and a third dataset with MEP center characteristics. While complete data on MEP engagements only dates back to 1999, the Ordowich et al. (Ibid.) study included all data available on MEP engagements between 1997 and 2002 to capture as many MEP clients as possible. Their study found about 47,000 engagements in the MEP database that were delivered to about 20,000 unique establishments between 1997 and 2002. Their modeling approaches included difference-in-differences (DiD) models and lagged dependent variable models to estimate the relationship between manufacturing extension and labor productivity. The DiD model for panel data is:

$$
\Delta \log \left(\frac{Y_{i t}}{L_{i t}}\right)=\Delta \lambda_{t}+\delta \Delta E x t_{i t}+\beta \Delta \log \left(\frac{K_{i t}}{L_{i t}}\right)+(\mu-1) \Delta \log \left(L_{i t}\right)+\Delta \varepsilon_{i t}
$$

The lagged dependent variable model for panel data is:

$$
\log \left(\frac{Y_{i t}}{L_{i t}}\right)=\alpha+\delta E x t_{i t}+\beta \log \left(\frac{K_{i t}}{L_{i t}}\right)+(\mu-1) \log \left(L_{i t}\right)+\theta \log \left(\frac{Y_{i t-1}}{L_{i t-1}}\right)+\varepsilon_{i t}
$$

Their results were mixed and suffered from several data limitations. As discussed in Angrist and Pischke (2009), the ideal situation is to estimate a fixed effects model with a lag term. ${ }^{5}$ However, as the Ordowich et al. study correctly pointed out, without stronger assumptions and more data,

\footnotetext{
5 Angrist and Pischke (2009), p. 245.
} 
such a combined model may lead to inconsistent estimates. ${ }^{6}$ In addition, the Ordowich et al. study tried several different instruments based on MEP center locations and other methods to correct for selection bias (such as propensity score matching), but none of these methods was correlated with the likelihood of an establishment being an MEP client in the same way that Jarmin (1999) reported.

This current study, commissioned by NIST MEP in 2012, builds on the Jarmin and Ordowich et al. studies by examining these relationships across three different years of Census of Manufactures (CMF) data $(1997,2002$, and 2007). This broader timeframe enables us to overcome Jarmin's focus on the pre-MEP extension period and Ordowich et al.'s focus on the recessiontainted 1997-2002 time period. Furthermore, this project builds on the results from these two models to bracket the effect of MEP services on labor productivity and output growth. ${ }^{7}$

\section{DATA AND METHODS}

The present study extends the analysis to the CMF for 2007, providing an additional period for observing productivity changes. The focus is on establishments that received MEP services between 1997 and 2007 in two time periods: 1997-2002 and 2002-2007. The unit of analysis for all analyses is the manufacturing establishment.

\footnotetext{
${ }^{6}$ To estimate a model with both differences and a lag, one must have data from more than two time periods and assume that error terms are only correlated across adjacent time periods.

7 Angrist and Pischke (2009), p.246-247.
} 


\subsection{DATA}

\subsubsection{NIST MEP Program Data}

As an initial step, we processed data on every establishment that received MEP services from 1997 to 2007 from the NIST MEP program. Most of these elements are contained in the NIST MEP Project Information File (PIF). ${ }^{8}$ For each MEP client, we received a project-level record containing various data elements, including unique IDs, project titles, the period MEP assistance was received, delivery mode, the type of assistance received, the number of MEP staff hours spent on the project, and the cost of the services provided. We also received a customer-level record that included client name, address, number of employees, and five-digit North American Industrial Classification System (NAICS) code. In addition, we received data on the MEP centers used to complete each project. Center-level data included the year the MEP center was started, number of staff in each center, total funding from NIST MEP for each center, location of each MEP center, market penetration rate for each center, and type of center (university/501(c)3/state agency).

The location of each center and auxiliary locations (e.g., other offices affiliated with the MEP center) was intended to be used to create an instrument for dealing with the problem of "selection bias" (in which higher productivity growth is a precondition for manufacturers that consider using MEP services). However, this instrument did not resolve the self-selection bias in the models that were estimated. Section 4.3.1 describes the other instruments (year of firm establishment, rurality of the county based on firm address) that were used. The distance from each establishment to the location of the nearest center's headquarters and offices was used as a control variable in the survival analysis model.

\footnotetext{
${ }^{8}$ Using some of these variables, we created variables to use in our analyses that quantified the total number of engagements for each establishment as well as the total number of cumulative hours of service provided by the MEP center.
} 
We initially labeled these establishments as manufacturers using the following process: (1) created a non-duplicate establishment name list comprising 61,919 records, 55,834 of which were "non-blank" in the "Name" field; (2) selected all establishments that had received service during the time period under analysis, which reduced the record count to 53,647; (3) separated manufacturing establishments from non-manufacturers based on the former's having NAICS codes in the CIF beginning with 31,32 , or 33 (for those lacking NAICS codes, we looked them up in Dun \& Bradstreet's Million Dollar Database and Reference USA); (4) reviewed the list of manufacturers and removed any that had manufacturing NAICS codes but were clearly not manufacturers (this was a manual process); (5) reviewed the list of non-manufacturers and added back any that appeared to be manufacturers (this also was a manual process, which found a particular clustering of what were actually manufacturers identified as having the NAICS code of "11111"); and (6) linked the resulting list to the PIF data about MEP projects. The resulting database had 38,067 manufacturers served from 1997 to 2007 that received an average of 3.3 project-based assists over this time period.

\subsubsection{Census Administrative Data}

Then, we accessed three databases through the Census Research Data Center (RDC) in Atlanta, Georgia, after securing approval from the U.S. Census Bureau and the Internal Revenue Service (IRS) to proceed with this study. These databases were the Standard Statistical Establishment Listing (SSEL), Longitudinal Business Database (LBD), and the Census of Manufactures (CMF). Because 1997 is the first year of our study, NAICS codes were used and there was no need for Standard Industrial Classification (SIC) code information for establishments. The Annual Survey of Manufactures (ASM) also was not used because small and midsize manufacturers are not fully represented in this database. 


\subsubsection{Standard Statistical Establishment Listing (SSEL) and Matching}

The SSEL contained many data elements for all establishments listed in the Business Register (BR). For this analysis, we used data elements such as EIN, Legal Form of Organization, NAICS code, State, County, Business Name, Mailing Address, and ZIP Code for all establishments listed in the Business Register between 1997 and 2007.

The project linked Census Bureau data to the MEP business assistance recipients. This was done using fuzzy logic code in the $\mathrm{R}$ programming software to match each establishment in the MEP data set to a unique establishment identifier in the SSEL. Generally, the researchers removed certain characters, such as commas, ampersands, slashes, and periods to leave only letters in the address field. Then, after standardizing common features such as "street", which may appear as "St." or "Street" or "St", as well as other features such as "road" and "avenue", the algorithm sought matches on combinations of establishment name and address to obtain the highest quality and number of matches. The $\mathrm{R}$ matching code enabled real-time review of individual matches. This process took from April 2014 to August 2014. During our review process, we observed that any record with a fuzzy matching score below $90 \%$ was likely not a true match. This high, but accurate, threshold resulted in a match rate of $20 \%$ (approximately 7,500 establishments). This match rate is similar to that in the Ordowich et al. study in terms of the number of MEP client establishments (7,737 MEP client establishments) that were matched in both the LBD and the CMF datasets. Indeed, after a visual inspection of the matched data at the $90 \%$ and lower scores, we are very comfortable with the quality of the matches using the $90 \%$ score as the threshold vis-à-vis some other score threshold. ${ }^{9}$ Nevertheless, we acknowledge that it is highly likely that unmatched MEP

\footnotetext{
${ }^{9}$ This low match rate calls for future collaboration between the Census Bureau, NIST MEP, and outside researchers to address recordkeeping and other data elements that facilitate accurate matches across time.
} 
clients exist in the control group (non-MEP clients), which means our results would be biased towards zero.

As we expected, the employment size distributions differed between matched and unmatched MEP clients. Looking only at the universe of establishments that received MEP services (from the raw MEP records), we find that the large majority of establishments have fewer than 250 employees. We subsequently used the unique establishment identifiers in each file (i.e., the Census file number and LBD number) to link the MEP business assistance records to the CMF and LBD data sets. As a result of the linkage of multiple data sets, we are left with approximately 7,500 matched MEP client establishments. For this subset, we see in Table 1 that $71 \%$ of matched MEP clients fell into three employment categories (20-99, 100-249, and 250-499). By contrast, we see that non-clients were more concentrated among smaller establishments, particularly the 1-19 employment category. Table 1 shows the distribution of MEP clients and non-clients, from the pool of matched establishments, across different employment size categories as well as the distribution of MEP clients across employment size categories before any matching occurred. That the distribution of establishments across employment size categories is somewhat consistent across the raw MEP records and the matched MEP clients suggests that the matching algorithm did not discriminate in favor of any particular size of establishments.

\section{[INSERT TABLE 1 ABOUT HERE]}

\subsubsection{Census of Manufactures}

The CMF includes all establishments in the manufacturing sector in years ending with a "2" and a "7". The most recent CMF data available for analysis at the Census Bureau at the time of our initial proposal to the Census Bureau were from the 2007 Census. Our analyses used data from the 1997, 2002, and 2007 CMF. The key variables obtained from the CMF include EIN, Legal Form of 
Organization, NAICS code, State, County, Total Employment, Number of Production Workers, Total Value of Shipments, Value-Added, Total Capital Expenditures, and Salaries and Wages.

The primary use of the CMF data was to provide key information on the establishments that was needed for the analysis, such as total employment (full-time equivalent or FTE), number of production workers, value-added, and capital expenditures (used in the capital to labor ratio). To meet Census Bureau disclosure requirements, the TVS variable was kept to conduct all disclosure analyses to enable release of the results from the Atlanta Census Research Data Center (RDC).

\subsubsection{Longitudinal Business Database}

The LBD comprises information to enable access to prior CMFs. This database was used to link to information from CMFs in 1997, 2002, and 2007. The project also used the LBD to link establishments across time to analyze survival as well as changes in key variables (such as sales growth), to obtain a measure of the establishment's age, and to identify establishments that are part of single-unit or multi-unit firms. LBD variables used included EIN, First Year Establishment is Observed, Last Year Establishment is Observed, and Single-Multi Unit Identifier.

Figure 1 illustrates the linkages between each of these datasets. 


\section{[INSERT FIGURE 1 ABOUT HERE]}

\subsection{VARIABLES}

The information in these MEP and Census Bureau databases was used to calculate variables to be used in our analyses. These variables are classified as either outcome, treatment, or control variables. Each variable and how it is calculated is described in Table 2. All dollar values were converted into 2007 dollars using the Consumer Price Index (CPI-U) for All Urban Consumers.

\section{[INSERT TABLE 2 ABOUT HERE]}

\subsection{MODELS}

Our analyses examine changes in productivity as a function of other variables and MEP assistance. In replicating and enhancing the analyses of the effect of MEP services on establishments performed by Jarmin (1999) and Ordowich et al. (2012), we encountered many of the same issues, including selection bias, the possibility of different methodologies giving us mixed results, limited time coverage, an overemphasis on quantitative measures of productivity, sales, and employment numbers that do not fully capture the effect of MEP in recessionary or slow economic growth periods. In addition to replicating the prior analyses, we performed new analyses (e.g., survival analysis) and considered additional CMF data (2007) that had been previously unavailable. The models we utilize in this evaluation are described below.

\subsubsection{Controlling for Selection Bias}

Generally, several interrelated issues need to be addressed when evaluating the effect of MEP services on establishment outcomes. First, establishments are likely more heterogeneous in terms of their characteristics than can be captured by a single-line ordinary least squares (OLS) regression equation. Second, selection bias occurs because establishments are not randomly assigned 
to the treatment and control groups; establishments select whether or not to become MEP clients. Jarmin (1999) found that companies with high sales growth but lower than average productivity selfselect into the group of MEP clients.

To control for self-selection bias, both Jarmin (1999) and Ordowich et al. (2012) used a Heckman two-stage model, which is also commonly referred to as an instrumental variables (IV) approach. For his instrument, Jarmin (1999) used a dummy variable to indicate whether or not an establishment is in an MSA with a manufacturing extension center. Ordowich et al. (2012) used a similar variable. The instrument was successful at controlling for self-selection bias in the Jarmin (1999) study (as it was correlated with client standing), but not in the Ordowich et al. (2012) study.

The current study also estimates an instrumental variable model using the age of the establishment and the 2003 USDA-ERS Rural-Urban Continuum Code (Rurality in $_{\text {) }}$ as instruments. The latter instrument ranges from 1 (counties with $1+$ million population) to 9 (completely rural counties with less than 2,500 population, not adjacent to a metro area). These instruments are correlated with the likelihood of an establishment being a client but are not correlated with labor productivity growth. In early testing, we also considered distance to the nearest MEP center as an instrument, but that variable failed to control for self-selection bias as it did not sufficiently distinguish client standing. We did use this variable in the survival analysis model to account for center effects based on distance from the closest MEP office alone. Table 3 shows, for matched establishments, the distribution of MEP clients and non-clients across the various rurality classifications.

\section{[INSERT TABLE 3 ABOUT HERE]}

In preliminary analyses, the Heckman correction for selection bias produced mixed results. For the DiD regression model that examined productivity differences between 2002 and 2007, the Heckman correction did not produce more efficient estimates. In other words, the instruments we 
used in the Heckman selection model (to handle the possible selection bias) did not make a statistically significant difference in the impact of MEP services on productivity differences. Therefore, we present the results of the OLS regression model below. However, for the DiD regression model estimated on the 1997 to 2002 period, the Heckman correction did produce more efficient estimates, but the coefficient on extension services was negative and significant, which is consistent with the Ordowich et al. (2012) study’s finding.

We anticipated finding and applying instruments that would control for selection bias. The age of the establishment and rural/urban location are correlated with client status, but not correlated with productivity growth, so presumably they would be good instruments. However, we had mixed success in applying them. Drawing on prior instruments used to control for selection bias, as well as using other instruments in this study, we were unable to find a single instrument that controlled for selection bias across all of the years in the study. Table 5 in the next section will show that MEP assisted clients had higher productivity (as measured by value-added per employee) and employment than non-clients, suggesting that the selection bias is a positive one. Future research could make progress on this part of the analysis by trying additional instruments, including instruments built on served and unserved establishments in the same firm or enterprise group. Nonetheless, we proceed with this study by estimating the impact of the variable of interest, receipt of MEP assistance, on productivity growth measures in an OLS framework.

\subsubsection{Difference-in-Differences (DiD) Model}

First, we replicated the DiD model in the Ordowich et al. (2012) study by re-estimating Equation 4. This model controls for time-invariant characteristics of each establishment. This includes both observable factors such as industry and location as well as unobservable factors such as management ability (Mundlak, 1961). This model is estimated for two changes in productivity 
(1997-2002, 2002-2007) for the set of continuing establishments as well as subsets of the data, including five different employment groups as well as different NAICS sectors. For establishments that survive through all three periods, this analysis tells us the differential impact of being served by the MEP in one of these two 5-year periods. We also consider productivity differences by employment size, industry, and substance of assistance and report on the use of instruments to address selection bias.

\subsubsection{Lagged Dependent Variable (LDV) Model}

Second, we replicated the lagged dependent variable model that was also used in the Ordowich et al. (2012) study by re-estimating Equation 5. With this model, variation in labor productivity in a given time period is expressed as a function of contemporaneous capital to labor ratios, contemporaneous employment, and labor productivity in a previous period. This model is estimated to show the degree to which estimates of the impact of MEP assistance on establishment productivity are validated by a different modeling approach. While the DiD model controls for the aforementioned time-invariant attributes of establishments, the LDV model accounts for baseline differences in productivity between served and unserved manufacturers and controls for the likelihood that the outcome variable is correlated over time (Angrist and Pischke 2009; Ordowich et al., 2012).

\subsubsection{Survival Analysis Models}

Survival analysis seeks to provide information on the factors that influence whether or not establishments survive from one period to the next. Survival analysis has been used to study a range of effects, from student attrition rates in universities to firm attrition rates from year to year. The basic goal is to estimate the shape of the hazard function for the underlying survival process of, in 
this research, manufacturing firms. We used two different models (Cox proportional hazards model and logit model) to test whether the receipt of MEP services increases the likelihood of survival from one time period to another.

In this study we tested very specific hypotheses about the characteristics of establishments that survive from period to period using the Cox proportional hazards model, with one of those characteristics being whether or not an establishment received MEP services. The Cox proportional hazards model requires the creation of two special variables: 1) a duration variable denoting the length of time a firm used MEP services (in years) and 2) a dichotomous variable denoting whether the endpoint is censored or not. CENSORED $=0$ if the firm continued to use MEP services by 2007 or CENSORED $=1$ if the firm stopped using MEP services by 2007. One limitation of using data in this format is that we cannot analyze "time-varying covariates" as a researcher might do using panel data.

The Cox model estimates a hazard function $h_{i}(t)=h_{0}(t) \exp \left(\beta_{1} x_{1}+\ldots+\beta_{k} x_{k}\right)$, where $i$ references each firm observation and $h_{0}(t)$ is the baseline hazard (that measures the value of the hazard function common to each firm before the other risk factors $x$ are taken into account). The hazard function can be rewritten in its familiar log form:

$$
\log h_{i}(t)=\log h_{0}(t)+\beta_{1} x_{1}+\ldots+\beta_{k} x_{k}
$$

In essence, this function tells us the aspects of firms that make an exit from the sample more or less likely in a given time interval. Using the method of maximum likelihood, the Cox model maximizes the Hosemer and Lemeshow (1989) partial log-likelihood function:

$$
L=\sum_{j=1}^{D}\left[\sum_{k \in D_{j}} x_{k} \beta-d_{j} \ln \left\{\sum_{i \in R_{j}} \exp \left(x_{i} \beta\right)\right\}\right] .
$$


The second model we used to test the likelihood of survival is the logit model, which estimates the probability of survival from one period to the next conditioned on a set of predictor variables. Mathematically, the logit model is written in its most familiar form as $=\frac{e^{\alpha+\beta X}}{1+e^{\alpha+\beta X}}$. For both the Cox model and the logit model, the dependent variable is coded $(0,1)$, where 0 indicates establishment survival between the two periods and 1 indicates an establishment's death. This operationalization, while counterintuitive compared to traditional OLS structures, is typical of survival analyses and facilitates the interpretation of odds ratios less than one in the Cox model as establishments having a lower probability of death, ceteris paribus. In the logit model, this operationalization facilitates the interpretation of an establishment's probability of death as increasing (positive coefficient) or decreasing (negative coefficient).

\section{RESULTS}

Our results begin with descriptive statistics of the primary variables used in the analysis. These are presented in Table 4. Note that the number of observations is rounded to the nearest thousand to satisfy Census Bureau disclosure requirements. ${ }^{10}$

\section{[INSERT TABLE 4 ABOUT HERE]}

Next, we conducted difference of means tests (using the student's t-statistics) of the differences in value-added, employment, and productivity between MEP clients and non-clients. MEP-assisted manufacturing establishments had higher levels of value-added and employment than non-clients (Table 5). These differences were significant at $\mathrm{p}<.05$ with the exception of valueadded per employee in 2002 and 2007.

\footnotetext{
${ }^{10}$ Some tabular and model details in subsequent parts of this section were not able to be released through the Census Bureau disclosure process. These are summarized in more general models or in text only.
} 


\section{[INSERT TABLE 5 ABOUT HERE]}

\subsection{DiD Model}

We replicated the DiD model used by Jarmin and Ordowich et al. over the 1997-2002 and 2002-2007 time periods. The specific model we used included more covariates than Equation 6. Specifically, we included controls for the age of the establishment - relating back to the focus of the program on established as opposed to startup manufacturers (Shapira et al., 2015) — and two industry class dummy variables to represent durables and nondurables based on these establishments' NAICS codes. This industry specification takes advantage of prior work into the greater productivity of durable as opposed to non-durable manufacturers in certain business cycles (Kehrig, 2011). The results show a positive but statistically insignificant coefficient for the extension variable in the 2002-2007 period (Table 6). ${ }^{11}$ Receiving MEP services between 2002 and 2007 is associated with 1.0 percent higher productivity (value-added per employee) growth compared to non-clients (in the DiD model), although again this result is not statistically significant at the 5 percent level. Other significant predictors of the change in logged value-added per employee (VA/EE) are the capital to labor ratio, the number of production workers, establishment age, and whether an establishment is located in a more urban or rural county.

\section{[INSERT TABLE 6 ABOUT HERE]}

We validated these results by using the same independent variables to explain variation in two different dependent variables: changes in the logged sales per production worker and changes in employment. We found a significant and positive impact of the extension variable on the natural log

\footnotetext{
${ }^{11}$ In interpreting this statistically insignificant result, keep in mind the possibility that some treated firms may erroneously be included in the control group, leading to a downward bias in the absolute value of the coefficients.
} 
of sales per production worker, ceteris paribus (Table 6). Receipt of MEP services in the 2002-to-2007 time period is associated with $2.6 \%$ higher sales per employee compared to non-clients. Also, we found a statistically significant and positive impact of MEP assistance on the natural $\log$ of employment (results not released). When we estimated the same model for the 1997-2002 period, we observed similar results as the Ordowich et al. (2012) paper reported (that productivity was statistically significant and lower for MEP customers). In sum, these findings suggest a level of consistency that enhances the reliability of their DiD results.

We tested the hypothesis of whether the sign and significance of the extension variable vary by the size or subsector of the manufacturing establishment. We estimated the same model specification across various subsets of our data. First, we divided establishments into the following size classes: Group $1=1$ to 19 employees; Group $2=20$ to 99 employees; Group $3=100$ to 249 employees; Group $4=250$ to 499 employees; and Group $5=500$ or more employees. Table 7 shows the impact of the extension variable on change in value-added per employee from 2002 to 2007 across the various groups based on total number of employees. The extension variable shows mixed results at this level of disaggregation: 3.0\% growth for Group 1 and 0.3\% growth for Group 2 versus $-6.3 \%$ for Group 3, $-7.2 \%$ for Group 4, and $0.2 \%$ for Group 5, although only the Group 3 and 4 coefficients are significant at the 95\% level of confidence. These results can be loosely interpreted as MEP services having the greatest effect on productivity for smaller establishments which, presumably, have fewer other alternative activities (e.g., other consulting activities, other activities aimed at increasing productivity) that affect outcomes. By contrast, larger manufacturers likely have other influences on manufacturing performance that could crowd out the effects of MEP services. As pointed out by a reviewer, one caveat of these results is that in 2012, establishments with 1-19 employees accounted for approximately 78\% of manufacturing establishments but only 
$9 \%$ of manufacturing employment and $4 \%$ of manufacturing value-added. Even if MEP assistance doubled the productivity of client establishments, the impact on overall productivity would be minor.

\section{[INSERT TABLE 7 ABOUT HERE]}

To examine differences by industry group, we divided establishments into a Durables subgroup (NAICS 33 sector) and a Non-Durables subgroup (NAICS 31 and 32 sectors). Based on the durable/non-durable bifurcation, we found significant differences in the impact of MEP assistance on productivity. Specifically, the coefficient on the extension variable (MEP assistance) was positive and significant at the $95 \%$ level of confidence for durables manufacturers and negative and insignificant, at the same confidence level, for non-durables (Table 8). Durables manufacturers receiving MEP services had 3\% higher growth in value-added per employee than non-clients in these industries over the 2002-to-2007 time period. These results are consistent with the positive productivity typically associated with durable, as compared with non-durable, establishments in certain business cycles and suggest that MEP assistance may serve to enhance these advantages (Kehrig, 2011).

\section{[INSERT TABLE 8 ABOUT HERE]}

We also examined differences in manufacturing productivity based on the type of manufacturing assistance provided. We grouped MEP substance codes into two categories to reflect a "top-line" (sales increasing) orientation versus a "bottom-line" (cost savings) orientation. The "top-line" substance group comprises business services and engineering/technical services; the "bottom-line" substance group comprises quality systems, manufacturing systems, information technology, and human resources and organizational development. We acknowledge that some bottom-line activities may spillover into the top-line activities and vice versa. However, because of the breadth of the substance codes used in the PIF, we judged that these groupings best proxy the differences in the two orientations. We subsequently weighted these two categories by the number 
of hours of effort associated with engagements in these categories and normalized the results by dividing by the total number of hours (because of variation in the number of hours of assistance across clients). We use this method to account for the common situation where MEP clients receive multiple types of services over the course of the period under study. Thus, the variable reflects the emphasis of the service in one substance category (versus another substance category) rather than a binary condition of selecting into (or not selecting into) a single substance code.

We then incorporated these variables into the DiD regression model covering the 20022007 time period in lieu of the extension variable. The "top-line" substance variable had a positive and statistically significant impact on the change in value-added per employee; the "bottom-line" variable had a negative and statistically insignificant impact on the change in value-added per employee. These results are not inconsistent with what might be expected. These results do not imply that "bottom-line" assistance should be eschewed; some firms may have a great need for it, including as an entry-level service (National Research Council, 2013). Although "bottom-line" assistance contributes to reducing the cost of goods and services, which is a component of valueadded, "top-line" assistance may augment the sales component of value-added more directly.

\subsection{LDV Model}

To validate the results of the DiD model, we also estimated the LDV model as was done in the Ordowich et al. (2012) study. The same covariates used in the DiD model were used in the LDV model, with the lagged version of the dependent variable being the only additional independent variable used in the model. For example, when the dependent variable is the natural log of labor productivity for 2002, the lagged variable is the natural log of labor productivity for 1997 . In the other model for the 2002-2007 period, the dependent variable is the natural log of labor productivity for 2007 and the lagged variable is the natural log of labor productivity for 2002 . 
The results of the LDV model are fairly consistent with those of the DiD model and are displayed in Table 9. Generally, in the LDV model spanning 1997-2002, MEP clients have statistically significant and positive productivity levels compared to non-clients overall (across all employment groups) and for the smallest employment levels (1 to 19 employees). Receipt of MEP services is associated with a $1.9 \%$ growth in value-added per employee (in the LDV model) during this period across all manufacturing categories, with a 5.3\% growth for clients in the 1 -to-19 employment range. This result is consistent with the Ordowich et al. evaluation done across the same time period. The independent variables used in these models are Ext, $\ln (\mathrm{K} / \mathrm{L})$ in period t, $\ln (\mathrm{Y} / \mathrm{L})$ in period t-1, Estab_age, Rurality, and MinDist, which are defined in Table 2.

For the period spanning 2002-2007, the LDV model suggests that MEP clients have statistically significant and positive productivity levels compared to non-clients for the 1-19 employee establishments; having received MEP services in this size class is associated with a 3.4\% growth in value-added per employee in the 2002-to-2007 time period. However, the sign for the MEP assistance variable changes to negative (while remaining statistically significant) for employment groups 100-249 and 250-499 employees. These results are quite consistent with the results of the DiD model results displayed in Table 7.

\section{[INSERT TABLE 9 ABOUT HERE]}

\subsection{Survival Analysis}

The Cox model is constrained to follow the proportional hazards assumption (which means that the hazard ratio is constant across time, not across observations). We confirmed in our preliminary testing that the data do not violate this assumption, which means there was no significant difference in the rate of change in the survival probabilities over time between establishments as a whole. However, the evidence suggests that there were significant differences in the survival probabilities for establishments that did and did not receive MEP services in the 1997- 
2007 period. Both models that were estimated come to the same conclusion about establishment survival being positively influenced by receipt of MEP assistance.

The results of the Cox model showed that establishments receiving MEP services had a significantly higher likelihood of surviving (i.e., MEP extension services had a significant and negative impact on establishment death rates). Put another way, MEP assistance increased the survival probabilities of establishments from 1997 to 2007. As for subsets of the data, extension services did not improve survival probabilities in the 1997 to 2002 period, which is consistent with what we observed in the productivity equation. But, extension services did improve survival probabilities in the 2002 to 2007 period. Using the results of the Cox model in Table 9 (assuming a Weibull distribution), the hazard ratio of 0.82 suggests that MEP client establishments are $18 \%$ less likely to die compared to non-clients and controlling for other factors. Also, the logit model results reinforce the Cox model results. The logit coefficient of -0.54 suggests that MEP client establishments have a lower probability of death relative to non-clients. Therefore, the increased survival of establishments receiving MEP services survives different econometric specifications, summarized in Table 10, across the 1997 to 2007 period. ${ }^{12}$

\section{[INSERT TABLE 10 ABOUT HERE]}

\section{CONCLUSIONS}

Overall, the results portray a nuanced picture of the ways in which MEP services impact productivity, sales, employment, and establishment survival when compared with a matched nonclient control group. This study considers the program as a whole and does not examine differences

\footnotetext{
12 The variable that measures the minimum distance to an MEP office was operationalized using a SAS routine that computes latitude and longitude coordinates. We then generated the minimum distance between an establishment and the nearest MEP office using the standard Haversine formula, which accounts for the circular nature of geographic distance.
} 
among centers. Potentially, the methodology could be applied to center-level comparisons, although the results would be less robust, as was shown in Ordowich et al. (2012), in part because of the smaller number of observations and client matches at the center-level.

We find, regardless of econometric model specification, that MEP clients with 1 to 19 employees have statistically significant and higher levels of labor productivity growth than nonclients in this employee size range. In contrast, the extension variable is not positively associated with higher productivity growth for MEP clients with 20 or more employees, and the coefficients on the extension variable are negative and significant for the largest MEP clients. Establishments in the medium-size employment category are often targeted as the most appropriate for MEP services, whereas the findings from this study_as well as the earlier Ordowich et al. (2012) studyunderscore the MEP's greater propensity to affect positive change in smaller establishments.

We observed significant productivity differences associated with MEP services by broad sector, with higher impacts for 2002-2007 in the durable manufacturing sector than in the nondurable manufacturing sector. One interpretation of this result is that MEP services may be particularly oriented to durable goods establishments such as machine shops, component suppliers, and other durable products manufacturers. Under this interpretation, it might not be surprising that these types of firms would be most apt to have positive growth in value-added per employee as a result of MEP services because MEP services are most suitable for their needs. It might also be plausible to suggest that the broader durable goods industry group fared better than the non-durable goods industry group over this time period (2002-2007), and this higher performance spilled over into better MEP client performance for this group. However, this interpretation is not supported by data from the U.S. Bureau of Economic Analysis. Durables had slower growth in current valueadded per employee than non-durables during these two time periods. Change in value-added per employee for durables for 1997-2002 was $-0.3 \%$ versus $0.4 \%$ for non-durables, while for 2002-2007 
it was $1.0 \%$ for durables versus $1.2 \%$ for non-durables. ${ }^{13}$ Therefore, it is particularly noteworthy that MEP clients in the durables sector saw significant positive growth in value-added per employee given these overall industry group trends. Another possible explanation is that durables manufacturers are best able to absorb MEP services, many of which are particularly oriented to these types of manufacturers.

We caution that while quantitative changes in value-added or sales are important program impact measures, many small firms cannot readily provide this information (Shapira et al., 2004). Additionally, MEP clients' productivity improvements may not raise overall manufacturing productivity, as indicated by BEA data for this period, if less productive firms crowd out more productive ones, as a general equilibrium approach might imply.

The results also show that establishments receiving MEP assistance have a statistically significant and higher probability of survival than those that do not receive MEP assistance. The longer-term survival of a manufacturing enterprise can also be an outcome of program intervention. Survival is not always unequivocally positive, however, especially if a federal program supports inefficient firms. The analyses presented here suggest that this outcome is generally unlikely in that MEP clients had higher productivity and employment. In an era of downward or slow economic growth, the ability to enable an establishment to be sufficiently competitive to survive as a result of MEP services may be an additional measure of program effect.

The program theory of the MEP, as discussed at the start of this paper, posits that intervention through supplying manufacturing assistance services will improve business performance. This study broadly confirms this program theory, in particular finding that MEP client companies have higher value-added per employee, greater growth in sales per employee, and greater probability

\footnotetext{
${ }^{13}$ Value-Added by Industry. Accessed November 17, 2014 from http://www.bea.gov.
} 
of survival. The qualification is that these results are most strongly positive for smaller firms than for medium-sized firms and for firms in durables industries. In addition, the paper presented two models (the DiD and the LDV models), which show broadly similar results, especially for smaller manufacturers. However, for the 2002-to-2007 period, neither model shows a positive and statistically significant coefficient for growth in value-added per employee. The reasons for this could be changes in the economic cycle, a possible shift in the services provided by the program, and the conceivable accumulation of repeat customers and other customers looking for services other than productivity improvement. Examples of the latter include services to address power and energy consumption, environmental issues, new product development, and strategic management; the results of these services may not readily appear in gross productivity valuations (Youtie et al., 2016). Further study to update the results of these models and to examine MEP impacts on other business outcomes would help to provide a fuller understanding of the MEP's results over a longer timeframe. 


\section{References}

Angrist, J., and Pischke, J-S. (2009). Mostly Harmless Econometrics, Princeton University Press: Princeton, NJ.

Griliches, Z. (1996). "The Discovery of the Residual: A Historical Note," Journal of Economic Literature, American Economic Association 34(3): 1324-1330.

Heckman, J. J. (1976). "The common structure of statistical models of truncation, sample selection and limited dependent variables and a simple estimator for such models," Annals of Economic and Social Measurement 5(4): 475-492.

Hosemer, D.W. and Lemeshow, S. (1989). Applied Logistic Regression. New York: John Wiley. Jarmin, R.S. (1999). "Evaluating the Impact of Manufacturing Extension on Productivity Growth," Journal of Policy Analysis and Management 18 (1): 99-119.

Kehrig, M. (2011). The cyclicality of productivity dispersion. US Census Bureau Center for Economic Studies Paper No. CES-WP-11-15.

Mundlak, Y. (1961). "Empirical Production Function Free of Management Bias," Journal of Farm Economics 43(1): 44-56.

NAPA (2003). The National Institute of Standards and Technology's Manufacturing Extension Partnership Report 1: Re-examining the Core Premise of the MEP Program, Washington, DC: National Academy of Public Administration.

National Research Council. (2013). 21 ${ }^{\text {st }}$ Century Manufacturing: The Role of the Manufacturing Extension Partnership. Board on Science, Technology, and Economic Policy. Washington, DC: The National Academies Press.

Ordowich, C., Cheney, D., Youtie, J., Fernandez Ribas, A., and Shapira, P. (2012). Evaluating the Impact of MEP Services on Establishment Performance: A Preliminary Empirical Investigation. U.S. Census Bureau Center for Economic Studies Paper No. CES-WP-12-15. 
Shapira, P. Youtie, J., Wang, J., Hegde, D., Cheney, D., Franco, Q., and Mohapatra, S. (2004). Assessing the V alue of Information and its Impact on Productivity in Small and Midsize Manufacturers. Georgia Institute of Technology and SRI International.

Shapira, P., and Youtie, J. (2014). Impact of Technology and Innovation Advisory Services. Nesta Working Paper 13/19. London: Nesta.

Shapira, P., Youtie, J., Cox, D., Uyarra, E., Gök, A., Rogers, J., \& Downing, C. (2015). Institutions for Technology Diffusion. Washington DC: Inter-American Development Bank.

Solow, R. (1957). "Technical Change and the Aggregate Production Function," Review of Economics and Statistics 39: 312-320.

U.S. Bureau of Economic Analysis. (2014). Value-Added by Industry. Accessed at [http://www.bea.gov/industry/gdpbyind data.htm]

Youtie, J. (2013). “An Evaluation of the MEP: A Cross-Study Analysis,” Appendix B, pp. 390-427, in: National Research Council (2013). 21 st Century Manufacturing: The Role of the Manufacturing Extension Partnership. Board on Science, Technology, and Economic Policy. Washington, DC: The National Academies Press.

Youtie, J., Shapira, P. Li, Y., and Dodonova, D. (2016). Innovation in Manufacturing: Needs, Practices, and Performance in Georgia 2016-2018. Retrieved from http://gms-ei2.org/wpcontent/uploads/2016/09/GMS-2016-report-of-surveyreduced.pdf. 
Figure 1. Datasets and Links

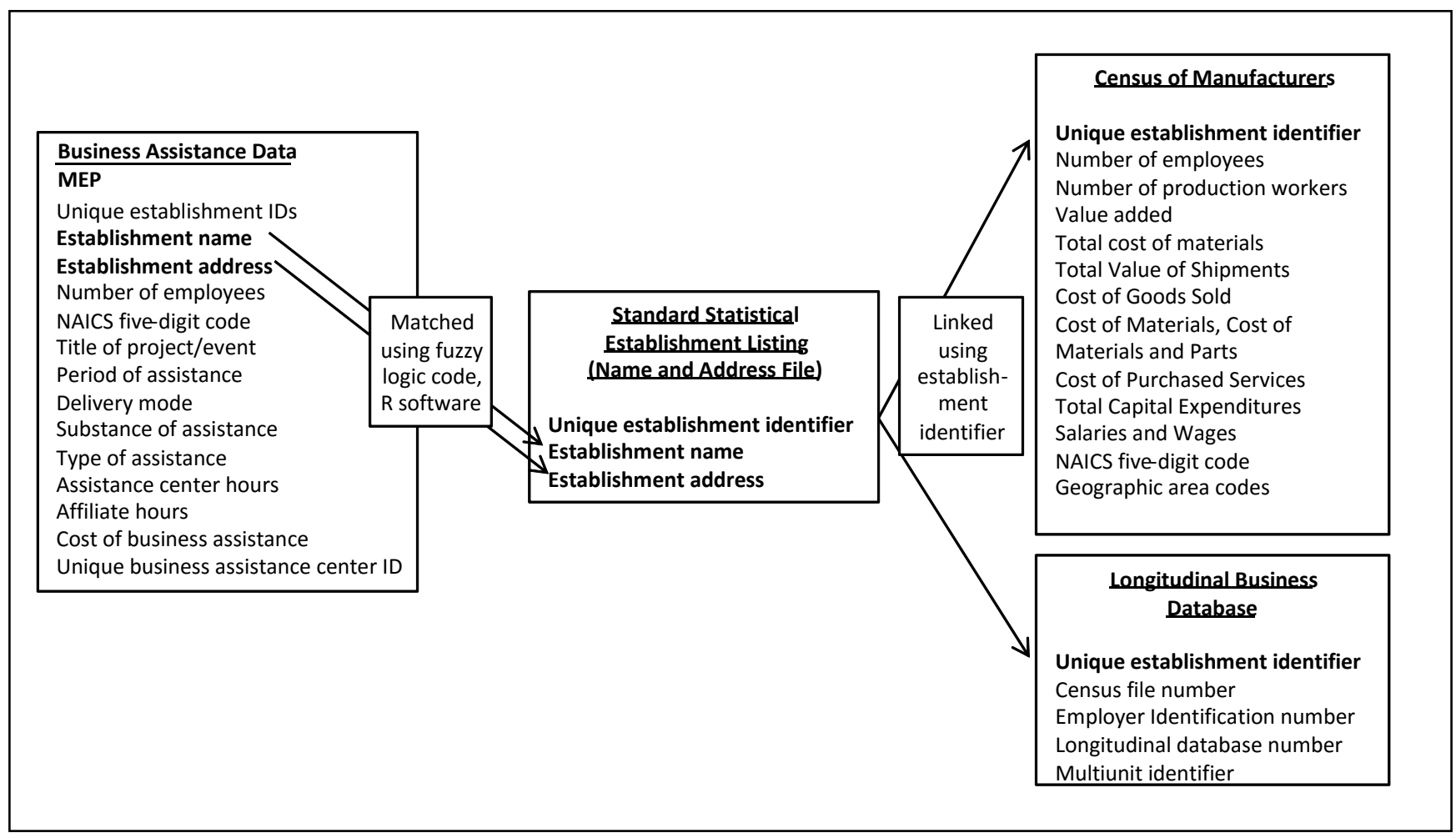


Table 1. Distribution of Matched MEP Clients and Non-Clients by Employment Size (2007)

\begin{tabular}{lcc|c}
\hline Employment Size Category & $\begin{array}{c}\text { Matched } \\
\text { MEP Clients }\end{array}$ & Non-Clients & Raw MEP Records \\
\hline 1 to 19 employees & $25 \%$ & $70 \%$ & $31 \%$ \\
20 to 99 employees & $46 \%$ & $22 \%$ & $37 \%$ \\
100 to 249 employees & $19 \%$ & $6 \%$ & $18 \%$ \\
250 to 499 employees & $6 \%$ & $2 \%$ & $9 \%$ \\
500 or more employees & $4 \%$ & $1 \%$ & $5 \%$ \\
\hline
\end{tabular}

Note: MEP clients, $\mathrm{N}>$ 7,500; Non-MEP clients $\mathrm{N}>300,000$; MEP records $\mathrm{N}=39,349$ 
Table 2. Variables Used in the Analyses

\begin{tabular}{|c|c|c|c|}
\hline Variable & Description & Source & Calculation \\
\hline \multicolumn{4}{|c|}{ Outcome Variables } \\
\hline$\frac{Y_{i t}}{L_{i t}}$ & $\begin{array}{l}\text { Value-added per employee } \\
\text { at establishment } i \text { in period } t\end{array}$ & $\mathrm{CMF}$ & $\begin{array}{l}\text { - Y: Value-added in } 2007 \\
\text { dollars } \\
\text { - L: number of production } \\
\text { workers }\end{array}$ \\
\hline$\frac{S_{i t}}{L_{i t}}$ & $\begin{array}{l}\text { Sales per employee at } \\
\text { establishment } i \text { in period } t\end{array}$ & $\mathrm{CMF}$ & $\begin{array}{l}\text { - Y: Value of shipments in } \\
2007 \text { dollars } \\
\text { - L: number of production } \\
\text { workers }\end{array}$ \\
\hline Surv1 & $\begin{array}{l}\text { Firm survival from one } \\
\text { period } t \text { to period } t+1\end{array}$ & LBD & $\begin{array}{l}\text { Coded as } 1 \text { if establishment is } \\
\text { not operating and } 0 \text { if } \\
\text { establishment is operating } \\
\text { (used in Cox model) }\end{array}$ \\
\hline \multicolumn{4}{|c|}{ Treatment Variables } \\
\hline$E x t_{i, X \rightarrow Y, Z}$ & $\begin{array}{l}\text { Binary variable for whether } \\
\text { a plant received MEP } \\
\text { services between years } X \\
\text { and } Y^{14}\end{array}$ & NIST-MEP & $\begin{array}{l}\text { Coded as } 1 \text { for received } \\
\text { services (all records from } \\
\text { NIST MEP) and } 0 \text { for all } \\
\text { other establishments (control } \\
\text { group from LBD/CMF) }\end{array}$ \\
\hline Substance $_{i}$ & $\begin{array}{l}\text { Substance of MEP } \\
\text { treatment }\end{array}$ & NIST-MEP & $\begin{array}{l}\text { Calculated based on summary } \\
\text { statistics by MEP center }\end{array}$ \\
\hline CumHours $_{i, X->Y, Z}$ & $\begin{array}{l}\text { The cumulative hours of } \\
\text { services received by } \\
\text { establishment } i \text { between } \\
\text { years } X \text { and } Y \text { on service } \\
\text { type } Z\end{array}$ & NIST-MEP & $\begin{array}{l}\text { Aggregated from NIST MEP } \\
\text { data based on number of } \\
\text { hours (center/affiliate) } \\
\text { devoted to services of } \\
\text { specified type over the time } \\
\text { period of interest }\end{array}$ \\
\hline \multicolumn{4}{|l|}{ Control Variables } \\
\hline$L_{i t}$ & $\begin{array}{l}\text { Number of employees and } \\
\text { production workers at } \\
\text { establishment } i \text { in period } t\end{array}$ & $\mathrm{LBD} / \mathrm{CMF}$ & $\begin{array}{l}\text { Total number of employees; } \\
\text { total number of production } \\
\text { workers }\end{array}$ \\
\hline$\frac{K_{i t}}{L_{i t}}$ & $\begin{array}{l}\text { Capital to labor ratio for } \\
\text { establishment } i \text { in period } t\end{array}$ & $\mathrm{CMF}$ & $\begin{array}{l}\text { - K: total capital expenditures } \\
\text { expressed in } 2007 \text { dollars } \\
\text { - L: number of production } \\
\text { workers }\end{array}$ \\
\hline NAICS $_{i}$ & $\begin{array}{l}\text { The five digit NAICS code } \\
\text { for establishment } i \text {, coded } \\
\text { into dummies for durables } \\
\text { and nondurables }\end{array}$ & $\mathrm{CMF}$ & $\begin{array}{l}\text { Directly from database; also } \\
\text { computed 2-digit sector } \\
\text { identifier and 3-digit subsector } \\
\text { identifier }\end{array}$ \\
\hline
\end{tabular}

14 Analysis by different time periods conducted to gauge how results change over time. Variables $\mathrm{X}$ and $\mathrm{Y}$ cover different time periods (1997 to 2002, 2002 to 2007, and 1997 to 2007). 


\begin{tabular}{|c|c|c|c|}
\hline Variable & Description & Source & Calculation \\
\hline MinDist $_{\mathrm{ij}}$ & $\begin{array}{l}\text { A continuous variable that } \\
\text { measures the distance of } \\
\text { establishment } i \text { to nearest } \\
\text { MEP center } j\end{array}$ & $\begin{array}{l}\text { SSEL/ } \\
\text { NIST MEP }\end{array}$ & $\begin{array}{l}\text { Use address from SSEL and } \\
\text { center data from NIST MEP } \\
\text { to identify the closest center } \\
\text { to each establishment in the } \\
\text { dataset }\end{array}$ \\
\hline InitProd $_{\mathrm{i}}$ & $\begin{array}{l}\text { Productivity of } \\
\text { establishment } i \text { in } 1997\end{array}$ & $\mathrm{CMF}$ & $\begin{array}{l}\text { Value-added in } 1997 \text { for } \\
\text { establishment } i\end{array}$ \\
\hline PrevSales $_{i}$ & $\begin{array}{l}\text { Previous (1992-1997) sales } \\
\text { growth of establishment } i\end{array}$ & $\mathrm{CMF}$ & $\begin{array}{l}\text { Use CMF data from } 1992 \text { to } \\
1997 \text { to calculate previous } \\
\text { sales growth }\end{array}$ \\
\hline InitCapInt $_{\mathrm{i}}$ & $\begin{array}{l}\text { Capital intensity level of } \\
\text { establishment } i \text { in } 1997\end{array}$ & $\mathrm{CMF}$ & $\begin{array}{l}\text { Capital to labor ratio for } \\
\text { establishment } i \text { in } 1997\end{array}$ \\
\hline Emp_group $_{i}$ & $\begin{array}{l}\text { Dummy variables for } \\
\text { different plant sizes } \\
\text { (number of employees) of } \\
\text { establishment } i \text { in } 2007\end{array}$ & LBD & $\begin{array}{l}\text { Number of employees in } 2007 \\
\text { in categories }\end{array}$ \\
\hline \multicolumn{4}{|c|}{ Instrumental Variables } \\
\hline Ruralityi & $\begin{array}{l}\text { Rural-Urban Continuum } \\
\text { Codes, } 2003,(1=\text { counties } \\
\text { with } 1+\text { million population, } \\
\ldots, 9=\text { completely rural } \\
\text { counties with less than } 2,500 \\
\text { population, etc.) }\end{array}$ & $\begin{array}{l}\text { US Department } \\
\text { of Agriculture, } \\
\text { Economic } \\
\text { Research Service }\end{array}$ & $\begin{array}{l}\text { Calculated based on county in } \\
\text { address data in SSEL }\end{array}$ \\
\hline Estab_age $_{\text {it }}$ & Age of plant $i$ in period $t$ & LBD & $\begin{array}{l}\text { Calculated as } 2011 \text { minus } \\
\text { commencement date of } \\
\text { establishment }\end{array}$ \\
\hline
\end{tabular}


Table 3. Matched Establishments, by MEP Clients and Non-Clients, Across the 2003 USDA-ERS Rural-Urban Continuum Codes

\begin{tabular}{|c|c|c|c|}
\hline $\begin{array}{l}\text { Continuum } \\
\text { Code }\end{array}$ & Description & $\begin{array}{c}\text { Did Not } \\
\text { Receive MEP } \\
\text { Services } \\
\end{array}$ & $\begin{array}{c}\text { Did Receive } \\
\text { MEP } \\
\text { Services } \\
\end{array}$ \\
\hline 1 & $\begin{array}{l}\text { Counties in metro areas of } 1 \text { million } \\
\text { population or more }\end{array}$ & $53 \%$ & $39 \%$ \\
\hline 2 & $\begin{array}{l}\text { Counties in metro areas of } 250,000 \text { to } \\
1 \text { million population }\end{array}$ & $18 \%$ & $24 \%$ \\
\hline 3 & $\begin{array}{l}\text { Counties in metro areas of fewer than } \\
250,000 \text { population }\end{array}$ & $9 \%$ & $12 \%$ \\
\hline 4 & $\begin{array}{l}\text { Urban population of } 20,000 \text { or more, } \\
\text { adjacent to a metro area }\end{array}$ & $5 \%$ & $8 \%$ \\
\hline 5 & $\begin{array}{l}\text { Urban population of } 20,000 \text { or more, } \\
\text { not adjacent to a metro area }\end{array}$ & $2 \%$ & $3 \%$ \\
\hline 6 & $\begin{array}{l}\text { Urban population of } 2,500 \text { to } 19,999 \text {, } \\
\text { adjacent to a metro area }\end{array}$ & $6 \%$ & $8 \%$ \\
\hline 7 & $\begin{array}{l}\text { Urban population of } 2,500 \text { to } 19,999 \text {, } \\
\text { not adjacent to a metro area }\end{array}$ & $3 \%$ & $5 \%$ \\
\hline 8 & $\begin{array}{l}\text { Completely rural or less than } 2,500 \\
\text { urban population, adjacent to a metro } \\
\text { area }\end{array}$ & $1 \%$ & $1 \%$ \\
\hline 9 & $\begin{array}{l}\text { Completely rural or less than } 2,500 \\
\text { urban population, not adjacent to a } \\
\text { metro area }\end{array}$ & $1 \%$ & $1 \%$ \\
\hline
\end{tabular}

Note: Cells are rounded, therefore columns may not sum to $100 \%$. Although 2013 codes are available, we used 2003 codes because they fell within the time frame of our analysis. 
Table 4. Descriptive Statistics

\begin{tabular}{lccc}
\hline & $\begin{array}{c}\text { Number of } \\
\text { Observations }\end{array}$ & Mean & $\begin{array}{c}\text { Standard } \\
\text { Deviation }\end{array}$ \\
\hline $\begin{array}{l}\text { Value-Added Per Employee in dollars, } \\
\text { 2002 }\end{array}$ & 360,000 & 98 & 645 \\
$\begin{array}{l}\text { Value-Added Per Employee in dollars, } \\
\text { 2007 }\end{array}$ & 339,000 & 110 & 506 \\
Sales Per Production Worker in dollars, & 356,000 & 306 & 2,718 \\
2002 & & & \\
Sales Per Production Worker in dollars, & 335,000 & 354 & 1,905 \\
2007 & 654,000 & 0.01 & 0.1 \\
MEP Client (Yes/No) & & & \\
$\begin{array}{l}\text { Distance to Nearest MEP Center in } \\
\text { miles }\end{array}$ & 542,000 & 51 & 65 \\
Establishment Age in years & 452,000 & 19 & 11 \\
Number of Production Workers, 2002 & 371,000 & 29 & 209 \\
Number of Production Workers, 2007 & 345,000 & 30 & 904
\end{tabular}


Table 5. Difference of Means Test Results

\begin{tabular}{|c|c|c|c|c|c|c|c|c|c|}
\hline $\begin{array}{l}\text { MEP Client } \\
\text { Status }\end{array}$ & \multicolumn{3}{|c|}{ Value-Added (VA) } & \multicolumn{3}{|c|}{ Employment (TE) } & \multicolumn{3}{|c|}{$\begin{array}{c}\text { Value-Added per } \\
\text { Employee (VA/EE) }\end{array}$} \\
\hline Year & 1997 & 2002 & 2007 & 1997 & 2002 & 2007 & 1997 & 2002 & 2007 \\
\hline Non-MEP Client & $\$ 4,759$ & $\$ 5,375$ & $\$ 8,120$ & 43 & 43 & 43 & $\$ 88$ & $\$ 101$ & $\$ 125$ \\
\hline MEP Client & $\$ 13,087$ & $\$ 14,645$ & $\$ 21,185$ & 121 & 112 & 111 & $\$ 106$ & $\$ 114$ & $\$ 133$ \\
\hline T-statistic & -11.83 & -11.41 & -9.74 & -27.07 & -6.82 & -3.32 & -7.06 & -1.48 & -1.04 \\
\hline Prob. (2-tail test) & 0.00 & 0.00 & 0.00 & 0.00 & 0.00 & 0.00 & 0.00 & 0.13 & 0.29 \\
\hline $\begin{array}{l}\mathrm{N}(\text { mepcust }=0)- \\
\text { rounded }\end{array}$ & 392,000 & 349,000 & 294,000 & 395,000 & 365,000 & 339,000 & 392,000 & 348,000 & 293,000 \\
\hline $\begin{array}{l}\mathrm{N}(\text { mepcust }=1)- \\
\text { rounded }\end{array}$ & 5,000 & 5,600 & 4,900 & 5,100 & 5,800 & 5,000 & 5,100 & 5,600 & 4,900 \\
\hline
\end{tabular}

Note: MEP clients, $\mathrm{N}>7,000$; Non-MEP clients $\mathrm{N}>300,000$. 
Table 6. DiD Regression Results, 2002-2007

\begin{tabular}{|c|c|c|c|c|}
\hline \multirow[b]{2}{*}{ Variable Name } & \multicolumn{2}{|c|}{$\begin{array}{c}\text { DV = Change in } \\
\ln (\text { Value-Added Per } \\
\text { Employee) }\end{array}$} & \multicolumn{2}{|c|}{$\begin{array}{c}\text { DV }=\text { Change in } \\
\ln \text { (Sales Per Production } \\
\text { Worker) }\end{array}$} \\
\hline & $\begin{array}{l}\text { Coefficient } \\
\text { Estimate }\end{array}$ & $\begin{array}{l}\text { T-statistic } \\
\text { (prob.) }\end{array}$ & $\begin{array}{l}\text { Coefficient } \\
\text { Estimate }\end{array}$ & $\begin{array}{l}\text { T-statistic } \\
\text { (prob.) }\end{array}$ \\
\hline Constant & 0.07 & $\begin{array}{l}14.77 \\
(0.00)\end{array}$ & 0.23 & $\begin{array}{l}53.94 \\
(0.00)\end{array}$ \\
\hline Change in $\ln$ (Capital to Labor & & 68.92 & & 105.09 \\
\hline Ratio) & 0.09 & $(0.00)$ & 0.13 & $(0.00)$ \\
\hline Change in $\ln$ (Number of & & -46.59 & & -111.73 \\
\hline Production Workers) & -0.13 & $\begin{array}{r}(0.00) \\
-14.19\end{array}$ & -0.34 & $\begin{array}{r}(0.00) \\
-43.92\end{array}$ \\
\hline Establishment Age & -0.002 & $\begin{array}{c}(0.00) \\
3.84\end{array}$ & -0.006 & $\begin{array}{c}(0.00) \\
6.54\end{array}$ \\
\hline Rural-Urban Continuum Code & 0.003 & $\begin{array}{c}(0.00) \\
1.07\end{array}$ & 0.004 & $\begin{array}{c}(0.00) \\
3.00\end{array}$ \\
\hline MEP Customer (Yes/No) & 0.01 & $(0.28)$ & 0.026 & $(0.00)$ \\
\hline $\begin{array}{l}\text { No. of Observations } \\
\text { (rounded) }\end{array}$ & \multicolumn{2}{|c|}{173,000} & \multicolumn{2}{|c|}{175,000} \\
\hline R-Squared & \multicolumn{2}{|c|}{0.07} & \multicolumn{2}{|c|}{0.28} \\
\hline F-statistic & \multicolumn{2}{|c|}{1,759} & \multicolumn{2}{|c|}{6,295} \\
\hline
\end{tabular}


Table 7. DiD Regression Results, by Employment Category, 2002-2007

DV $=$ Change in $\ln ($ Value-Added Per Employee $)$

\begin{tabular}{lcccccc}
\hline & All & & & & & $\mathbf{5 0 0}$ or \\
No. of Employees & Groups & $\mathbf{1 - 1 9}$ & $\mathbf{2 0 - 9 9}$ & $\mathbf{1 0 0 - 2 4 9}$ & $\mathbf{2 5 0 - 4 9 9}$ & more \\
\hline No. of Observations & & & & & & \\
(Rounded) & 173,000 & 99,000 & 50,000 & 16,000 & 5,000 & 3,000 \\
MEP coeff estimate & 0.011 & 0.030 & 0.003 & -0.063 & -0.072 & 0.002 \\
T-statistic & 1.07 & 1.20 & 0.26 & -2.85 & -1.89 & 0.05 \\
\hline
\end{tabular}


Table 8. DiD Regression Results, 2002-2007, by NAICS Industries

DV $=$ Change in $\ln$ (Value-Added Per Employee)

\begin{tabular}{|c|c|c|c|c|}
\hline \multirow[b]{2}{*}{ Variable Name } & \multicolumn{2}{|c|}{$\begin{array}{c}\text { Non-Durable } \\
\text { (NAICS } 31 \text { and 32) }\end{array}$} & \multicolumn{2}{|c|}{$\begin{array}{c}\text { Durable } \\
\text { (NAICS 33) }\end{array}$} \\
\hline & $\begin{array}{l}\text { Coefficient } \\
\text { Estimate } \\
\end{array}$ & $\begin{array}{c}\text { T-statistic } \\
\text { (prob.) }\end{array}$ & $\begin{array}{l}\text { Coefficient } \\
\text { Estimate }\end{array}$ & $\begin{array}{c}\text { T-statistic } \\
\text { (prob.) }\end{array}$ \\
\hline Constant & 0.08 & $11.10(0.00)$ & 0.06 & $9.69(0.00)$ \\
\hline Change in $\ln (\mathrm{K} / \mathrm{L})$ & 0.10 & $48.15(0.00)$ & 0.09 & $49.02(0.00)$ \\
\hline Change in $\ln (\mathrm{PW})$ & -0.16 & $-34.83(0.00)$ & -0.11 & $-30.94(0.00)$ \\
\hline EstabAge & -0.003 & $-11.42(0.00)$ & -0.001 & $-8.48(0.00)$ \\
\hline Continuum Code & 0.004 & $3.42(0.00)$ & 0.002 & $1.93(0.00)$ \\
\hline MEP Customer & -0.029 & $-1.65(0.10)$ & 0.03 & $2.42(0.02)$ \\
\hline $\begin{array}{l}\text { No. of Observations } \\
\text { (rounded) }\end{array}$ & 78,000 & & 95,000 & \\
\hline R-Squared & 0.08 & & 0.06 & \\
\hline F-statistic & 924 & & 850 & \\
\hline
\end{tabular}


Table 9. LDV Regression Results, by Employment Category, 1997-2002 and 2002-2007

DV $=$ Change in $\ln$ (Value-Added Per Employee $)$

\begin{tabular}{|c|c|c|c|c|c|c|}
\hline 1997-2002 & $\begin{array}{c}\text { All } \\
\text { Groups }\end{array}$ & $1-19$ & 20-99 & $100-249$ & $250-499$ & $\begin{array}{l}500 \text { or } \\
\text { more }\end{array}$ \\
\hline No. of Observations (Rounded) & 186000 & 120000 & 48000 & 13000 & 4000 & 3000 \\
\hline MEP coeff estimate & 0.019 & 0.053 & 0.012 & -0.012 & 0.004 & -0.002 \\
\hline T-statistic & 2.330 & 3.290 & 1.080 & -0.670 & 0.130 & -0.060 \\
\hline \multicolumn{7}{|l|}{$2002-2007$} \\
\hline No. of Observations (Rounded) & 186000 & 107000 & 55000 & 16000 & 5000 & 3000 \\
\hline MEP coeff estimate & -0.014 & 0.034 & -0.006 & -0.077 & -0.072 & 0.010 \\
\hline T-statistic & -1.650 & 1.930 & -0.530 & -3.840 & -1.980 & 0.180 \\
\hline
\end{tabular}


Table 10. Weibull and Logit Regression Estimates

\begin{tabular}{|c|c|c|c|c|c|c|}
\hline \multirow[b]{2}{*}{ Variable } & \multicolumn{3}{|c|}{ Weibull Model } & \multicolumn{3}{|c|}{ Logit Model } \\
\hline & Hazard Ratio & Z-statistic & Prob. & $\begin{array}{c}\text { Coefficient } \\
\text { Estimate }\end{array}$ & Z-statistic & Prob. \\
\hline Constant & $3.55 \mathrm{E}-010$ & -178.13 & 0.00 & -0.01 & -2.16 & 0.03 \\
\hline Estab Age & 0.67 & -166.70 & 0.00 & -0.02 & -70.00 & 0.00 \\
\hline VA97 & 1.00 & 1.41 & 0.15 & --- & --- & --- \\
\hline VA02 & 1.00 & -0.70 & 0.48 & --- & --- & --- \\
\hline VA07 & 1.00 & 1.66 & 0.09 & --- & --- & --- \\
\hline TE97 & 1.00 & 23.63 & 0.00 & --- & --- & --- \\
\hline TE02 & 1.00 & 8.78 & 0.00 & --- & --- & --- \\
\hline TE07 & 0.99 & -37.78 & 0.00 & --- & --- & --- \\
\hline MEP Customer & 0.82 & -3.92 & 0.00 & -0.54 & -18.56 & 0.00 \\
\hline Min Distance & 1.00 & 2.83 & 0.01 & & & \\
\hline $\mathrm{p}$ & 9.47 & & & $\begin{array}{c}\text { Pseudo R2 } \\
\text { N }\end{array}$ & 0.01 & \\
\hline $1 / \mathrm{p}$ & 0.10 & & & (Rounded) & 452,000 & \\
\hline N (Rounded) & 161,000 & & & $\log \mathrm{L}$ & $-301,235$ & \\
\hline $\log \mathrm{L}$ & $-36,803$ & & & & & \\
\hline
\end{tabular}




\section{Acknowledgements}

The authors gratefully acknowledge the ideas and guidance received from the Technical Advisory Group: Ron Jarmin, U.S. Census Bureau; David Beede, U.S. Department of Commerce; Barbara Fraumeni, Hunan University (China); and Carolyn Heinrich, University of Texas. Additional comments were appreciatively received from Susan Helper and Cassandra Ingram, U.S. Department of Commerce, and Kenneth P. Voytek, NIST-MEP. This project was prepared for NIST-MEP, Contract \# SB1341-11-SE-1446. The findings and observations contained in this report are those of the authors and do not necessarily reflect the views of the Technical Advisory Group or the sponsor (National Institute for Standards and Technology, Manufacturing Extension Partnership). Any opinions and conclusions expressed herein are those of the author(s) and do not necessarily represent the views of the U.S. Census Bureau. All results have been reviewed to ensure that no confidential information is disclosed.

\section{Author Biographies}

Clifford A. Lipscomb is the Vice Chair and Co-Managing Director of Greenfield Advisors, an economic and real estate consulting firm with offices in Seattle, WA and Cartersville, GA.

Jan Youtie is Director of Policy Research Services at the Georgia Tech Enterprise Innovation Institute.

Philip Shapira is Professor of Innovation Management and Policy at the University of Manchester, and Professor of Public Policy at Georgia Institute of Technology.

Sanjay Arora is a Senior Data Scientist at the American Institutes for Research in Washington, DC.

Andy Krause is a Lecturer in the Department of Property at the University of Melbourne. 